\title{
THE EFFECT OF ORGANIZATION LEARNING CAPABILITY AND ORGANIZATIONAL INNOVATION ON COMPETITIVE ADVANTAGE AND BUSINESS PERFORMANCE
}

\author{
Zainurrafiqi", Gazali, Nuzulul Qurnain \\ Department of Management, University of Madura, Indonesia \\ Nurul Hidayati \\ Institut Dirosat Islamiyah Al-Amien (IDIA), Indonesia \\ `E-mail: zainurrafiqi@unira.ac.id.
}

\begin{abstract}
Entering the industrial revolution era 4.0, MSMEs are required to have products with special characteristics, unique and different than other competitors. Therefore, MSMEs can develop its local wisdom as Competitive Advantage and create a market with its own characteristics. So that competition in this case is no longer related to "excellence" but "related to efforts to create and maintain product uniqueness". To be competitive does not mean to win by eliminating competitors, but because of the element of difference and worthy of juxtaposition without turning off the opponent's product. The sampling technique uses Convenience Sampling. The samples are 300 MSMEs. Data analysis uses the Structural Equation Model program. The results of this research indicate Organizational Learning Capability and Organizational Innovation have a positive and significant effect on the Competitive Advantage and Competitive Advantage has a positive and significant effect on the Business Performance.
\end{abstract}

\section{KEY WORDS}

Competitive advantage, organization, learning capability, organizational innovation, business performance.

Entering the industrial revolution era 4.0, the MSMEs are required not only to produce products that seem to only imitate or rely on quantity, but MSME products should have a unique and different among other products. This matter could develop well, if the MSMEs can continue to explore the local wisdom of their respective regions and create their own unique marketplace.

Local wisdom can be developed and optimized through an implicational approach of Organizational learning capability and Organizational innovation, the impact could create competitiveness based on local wisdom, improving the performance of MSMEs and eventually it hopes to reduce poverty levels in the Prasional sub-district. Calantone et.al, (2002) and Céspedes et.al, (2005), Zhou et al. (2019), Migdadi (2019), Jafari \& Zolfagharian (2019), Hooi (2019), Salisu \& Mohammed (2019), Yusoff et al. (2019), practice of Organizational learning capability will create knowledge transfer, openness, experimentation managerial commitment and system perspective. While the implementation of Organizational innovation will create New Organizanisational Method, workplace organizations and business practices for external relations (Camisón and Villar, 2010; Phan, 2019; Chen et al., 2020; Waheed et al., 2019; Chaubey et al., 2019; Zhou et al., 2019).

With the development of local wisdom-based product competitiveness, the MSMEs of Pragaan District has special target of consumers and prioritizes niche areas. Even though they are in a small place, with good space and local uniqueness, local products can still compete with imported products that have their own core values. So that competition in this context will change the paradigm. It's no longer a "competition of excellence" but shifted meaning to "efforts to maintain the uniqueness of the product". To be competitive does not mean to win by eliminating competitors, but because of the element of difference and worthy of juxtaposition without turning off the opponent's product. 
The purposes of this research are to test the effect of Organizational learning capability on Organizational innovation, Organizational Innovation on Competitive Advantageand and Competitive Advantage on Business Performance.

\section{HYPOTHESIS DEVELOPMENT}

Organization Learning Capabilities. Spott, (2015) innovation is part of organizational learning, some research that shows the relationship between innovation and learning ability. Previous research stated that empirically companies were motivated to engage learning abilities in improving the performance of technical innovation. However, there is no detailed research related to the effect of organizational learning capacity on non-technical innovation.

While the research conducted by Moustaghfir and Schiuma (2013) shows different results, namely the external relational learning capacity and internal relational learning capacity are significantly influence the intensity of non-technical innovation.. King (2009) learning ability can support organizational innovation through different channels. Cross and Sam (2009) Quality management practices and organizational learning are complementary tools. Chen et.al (2009), the formation of external relations supported by organizational learning". Based on the explanation above, we propose the following hypothesis:

H1: Organization Learning Capabilities has a positive and significant effect on Organizational Innovation.

Organizational Innovation. According to Camisón and Villar, 2010 innovation is the core and main source of competitive advantage, while in other case Competitive advantage can be created by implementing corporate value creation strategies that are still not used by major competitors (Howard and Marshall, 2012). While in other opinion Walker (2009), stated that competitive advantage is related to a company's dynamic ability to innovate, adapt and maximize its resources and capabilities. Bansemir, (2013) Organizational innovation implements a specific system that can help companies; this system involves various kinds of relationships and participants among the people involved in the organization. "Walker et.al, (2010) analyzed the relationship between innovation and company performance, finding supportive results". While previous studies do not provide clear conclusions about the relationship between organizational innovation and competitive advantage. Organizational innovation is a factor that leads to superior performance. Instead, the research discusses the concept of competitive advantage and examines the effect of organizational innovation on competitive advantage, which usually considers organizational innovation as a part of broader latent construction that also includes the product and process innovation (Nandram, 2014). From the discussion above, we propose the following hypothesis:

H2: Organizational Innovation has a positive and a significant effect on Competitive Advantage.

Competitive Advantage. There are changes related to the process of value creation, because changes are related to the competitive ability of intangible physical forms, based on the activities and knowledge of the company. Competitiveness is determined by scarce, valuable and difficult to imitate resources in an organization, so that competitiveness is not created by technology, economies of scale and natural resources, because if guided by those factors, the impact of competitiveness is easier to imitate ( Shams, (2013). Shams, (2013) defines competitive advantage as the ability to generate investment returns continuously above the industry average, and that competitive advantage can be achieved by implementing a value creation strategy that is not implemented by other competitors. Research conducted by McGrath, (2013) concluded that intellectual capital has a positive and significant effect on competitive advantage and business performance. Companies can create competitive advantage by applying their intellectual capital in the form of their knowledge, strategic capabilities, technological skills and experience. From the discussion above, we propose the following hypothesis:

H3: Competitive Advantage has a positive and a significant effect on Business Performance. 


\section{METHODS OF RESEARCH}

This research was conducted at MSMEs in the Pragaan District, Sumenep Regency. The reason of choosing Pragaan District it because Pragaan is one of the business centers in Sumenep Regency and also rich in local wisdom it is worthy of calculation and has a commitment to improve business competitiveness globally. Pragaan District which consists of 14 villages that each village has their own uniqueness related to local wisdom. The list of 14 villages were Aeng Panas, Jaddung, Kaduara Timur, Karduluk, Larangan Perreng, Pakamban Daya, Pakamban Laok, Pragaan Daya, Pragaan Laok, Prenduan, Rombasan, Prangaan, Sendang, Sentol Daya and Sentol Laok. According to Bentler and Chou, (1987), the rules regarding the normal size distribution of samples to calculate free parameters, namely the lowest ratio of 5 respondents in each observed variable will suffice for normal distribution when a latent variable has several indicators or observed variables and a ratio of 10 respondents per observed variable will be sufficient for other distributions, so that the sample size in this study is 156 samples. However, in order to obtain reliable data, this study published 300 questionnaires for MSMEs managers in the Pragaan District. This research is including in Exploration research category. The researcher does the Hypothesis testing in order to support or reject hypotheses. Following this research model as follows:

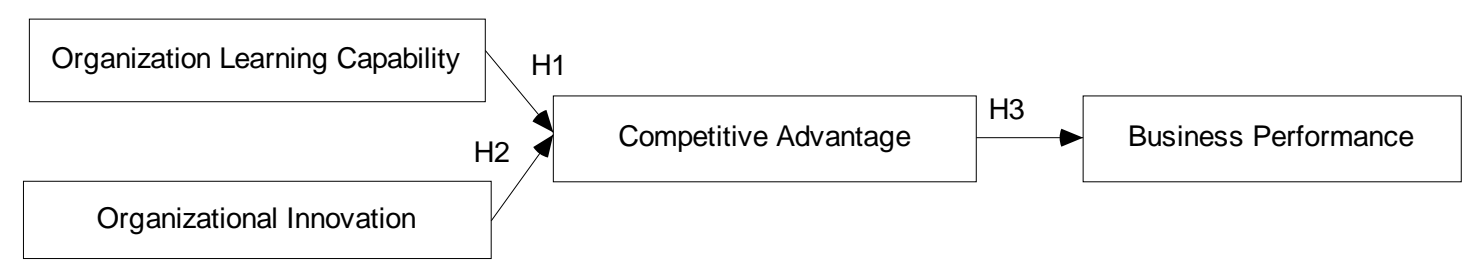

Figure 1 - Research model

The variables of the research were measured on a Likert scale with a range from 1 to 7 where 1 equals "Strongly disagree" and 7 equals "Highly agree". The variables studied consisted of exogenous variables and endogenous variables.

Table 1- The Standard Estimation of Overall Model Fit

\begin{tabular}{ll}
\hline Index & Standard of Estimation \\
\hline Absolute Fit Indices & \\
Chi-squire (X2/df) & $\leq 2$ \\
Goodness of Fit (GFI) & $\geq 0.9$ \\
Adjusted Goodness of Fit (AGFI) & $\geq 0.9$ \\
Root Mean Square Error of Approximation (RMSEA) & $\leq 0.05$ \\
Root Mean Square of Residual (RMR) & $\leq 0.05$ \\
Incremental Fit Indices & $\geq 0.9$ \\
Normed fit index (NFI) & $\geq 0.9$ \\
Non-normed Fit Index (NNFI) & $\geq 0.9$ \\
Comparative fit index (CFI) & $\geq 0.05$ \\
Parsimony Fit Indices & $\geq 0.05$ \\
Parsimonious Goodness of Fit Index (PGFI) & \\
Parsimonious Normed Fit Index (PNFI) & \\
\hline
\end{tabular}

Source: MacCallum and Sugawara, 1996 and Hooper and Mullen, 2008.

Latent Exogenous Variable: (1) Organizational learning capability, measured by 3 items for Managerial Commitment, 3 items for System perspective,4 items for Openness and experimentation, 2 items for Knowledge Sharing which are adopted by Calantone et.al, (2002) and Céspedes et.al, (2005). (2) this research adopted the theory Camisón and Villar, (2010) about Organizational innovation, the theory measured by 3 items of Organizational innovation method for external relations, 3 items for Organizational innovation in work place organizations, 3 items for Organizational innovation in business practices. In Latent Endogenous Variable are which is adopted from Kearns, and Lederer, (2003): 
(1) Competitive Advantage, measured by 7 items for Growth, 6 items for Innovation, 7 items for Differentiation, 5 items for Partnership, 7 items for Cost reduction. (2) Business Performance, measured by 3 items for Financial performance, 3 items for Marketing performance, which are adopted by Hooley and Greenley, (2005).

This study uses Structural Equation Model analysis to study about linear relationship between variables, testing hypotheses and causal relationships between variables using the software AMOS 17. As for the requirements that must be discussed in Structural Equation Modeling test can be seen in Table 1 as follows (MacCallum and Sugawara, 1996) and (Hooper and Mullen, 2008).

\section{RESULTS AND DISCUSSION}

There are 2 steps in the analysis of the Structural Equation Model. The first is Measurement Model and the second is Structural Model (Kaplan, 2000).

Table 2 - The Measurement Model Fit Result

\begin{tabular}{ll}
\hline Index & Result \\
\hline Chi-squire (X2) & 109.25 \\
Chi-squire DF & 54 \\
Chi-squire (X2/df) & 2.02 \\
Goodness of Fit (GFI) & 0.92 \\
Comparative fit index (CFI) & 0.94 \\
Root Mean Square of Residual (RMR) & 0.06 \\
Non-normed Fit Index (NNFI) & 0.92 \\
Adjusted Goodness of Fit (AGFI) & 0.86 \\
Normed fit index (NFI) & 0.91 \\
Root Mean Square Error of Approximation (RMSEA) & 0.07 \\
\hline
\end{tabular}

Source: Data that have been processed by AMOS.

Table 3 - Scale Composite Reliability and Convergent Validity Analysis

\begin{tabular}{|c|c|c|c|c|c|}
\hline & Construct (F) and Indicators (V) & $\begin{array}{l}\text { Standardized } \\
\text { Loading }\end{array}$ & t value & $\begin{array}{l}\text { Indicator } \\
\text { Reliability }\end{array}$ & $\begin{array}{l}\text { Composite } \\
\text { Reliability }\end{array}$ \\
\hline \multicolumn{6}{|c|}{ Organizational Learning Capability (F1) } \\
\hline V1 & Managerial Commitment & 0,82 & 19,84 & 0,63 & \multirow{4}{*}{0.84} \\
\hline $\mathrm{V} 2$ & System perspective & 0,84 & 21.18 & 0.76 & \\
\hline V3 & Openness and experimentation & 0.81 & 19.76 & 0.66 & \\
\hline V4 & Knowledge Sharing & 0,96 & 26.85 & 0.93 & \\
\hline \multicolumn{6}{|c|}{ Organizational Innovation (F2) } \\
\hline V5 & Organizational innovation in business practices & 0,97 & 26.54 & 0.93 & \multirow{4}{*}{0.95} \\
\hline V6 & Organizational innovation in work place organizations & 0.83 & 19.93 & 0.65 & \\
\hline V7 & Organizational innovation method for external relations & 0.93 & 24.69 & 0.86 & \\
\hline \multicolumn{5}{|c|}{ Competitive Advantage (F3) } & \\
\hline V8 & Differentiation & 0.89 & 22.50 & 0.70 & \multirow{5}{*}{0.92} \\
\hline V9 & Cost reduction. & 0.87 & 22.43 & 0.68 & \\
\hline V10 & Innovation & 0.81 & 19.22 & 0.63 & \\
\hline V11 & Growth & 0.92 & 24.72 & 0.82 & \\
\hline V12 & Partnership & 0.96 & 26.43 & 0.91 & \\
\hline \multicolumn{6}{|c|}{ Business Performance (F4) } \\
\hline V13 & Marketing performance & 0.95 & 26.38 & 0.86 & \multirow[t]{2}{*}{0.89} \\
\hline V14 & Financial performance & 0.91 & 22.60 & 0.79 & \\
\hline
\end{tabular}

Source: Data that have been processed by AMOS.

Measurement models are performed using the Confirmatory Factor Analysis (CFA) method. The eligibility measurement requirements include Chi-square (X2), Adjusted Goodness of Fit (AGFI), Comparative fit index (CFI), Goodness of Fit (GFI), Root Mean Square of Approval (RMSEA), and other indicators that added as an overall indication of the Feasibility Measurement model (Hooper and Mullen, 2008). The results of data analysis in Table 2 show that $\mathrm{X} 2$ / df-ratio is 2.02, namely at interval 3. This shows that the model has been accepted. NNFI, CFI, NFI and GFI, which is greater than or beyond 0.9 , It can be regarded that NNFI, CFI, NFI and GFI, has met the acceptable requirements. The RMSEA 
value is 0.07, and is still accepted because according to MacCallum and Sugawara (1996), an RMSEA value of 0.05 to 0.10 is acceptable. Regarding measurements in this study indicate eligibility for the model.

In Table 3, it can be seen that the Composite Reliability is placed between 0.8 , the value recommended by Fornell and Larcker (1981). The Composite approval value greater than 0.60 , based on the results of these tests, it can be concluded that the Measurement Model related to reliability has obtained all the requirements for the test variable.

Convergent Validity scale measurement in this study is using Confirmatory Factor Analysi (see table 3 ), the value of $t$ test shows greater than 1.96, it means that the Standardized Loading for all observed variables is significant. All this shows that the path coefficient value is significant, and this is evidence that the results of the indicator meet the Convergent Validity requirements (Anderson and Gerbing, 1988).

The purpose of discriminant validity testing is to find out the high or low correlation coefficient between two variables. The higher the correlation coefficient between two variables, then there is a possibility that the discriminant validity indication cannot be fulfilled. To test the discriminant validity of this research is to compare "Organizational Learning Cability" and " Business Performance" with a correlation coefficient of 0.81, with p-values $<0.05$ and "Organizational Learning ability" and "Competitive Advantage " with coefficients correlation of 0.72 with $p$-value $<0.05$, all was done to prove that both pairs of variables have discriminant validity.

Table 4 - Discriminant Validity Analysis

\begin{tabular}{|c|c|c|c|c|c|c|}
\hline & $\begin{array}{l}\text { Correlation } \\
\text { Coefficient }\end{array}$ & & $\begin{array}{l}\text { Unidimensional } \\
\text { Measurement Model }\end{array}$ & $\begin{array}{l}\text { Measurement } \\
\text { Model }\end{array}$ & $\begin{array}{l}\text { The } \\
\text { difference }\end{array}$ & $\begin{array}{l}P \\
\text { value } \\
\end{array}$ \\
\hline $\begin{array}{l}\text { Organizational Learning Capability } \\
\leftrightarrow \text { Competitive Advantage }\end{array}$ & $0.72^{* \star \star}$ & $\begin{array}{l}\text { Chi- } \\
\text { square }\end{array}$ & 978.87 & 435.75 & 543.12 & $<0.05$ \\
\hline $\begin{array}{l}\text { Organizational Learning Capability } \\
\leftrightarrow \text { MSME performance }\end{array}$ & $0.81^{\star \star *}$ & $\begin{array}{l}\text { DF } \\
\text { Chi- } \\
\text { square }\end{array}$ & $\begin{array}{l}149 \\
632.45\end{array}$ & $\begin{array}{l}148 \\
234.21\end{array}$ & $\begin{array}{l}1 \\
398.24\end{array}$ & $<0.05$ \\
\hline & & DF & 148 & 147 & 1 & \\
\hline
\end{tabular}

Note: ${ }^{* *} p<0.001$. Source: Data that have been processed by AMOS.

The test results in Table 4 show the chi-square value between the test of unidimensional model and the measurement model for one pair are different. It can be concluded that the value is significant. In general, all measurements show the discriminant validity test has been fulfilled, as evidenced by the greatest correlation value between the variables is significantly different.

This study aims to determine the effect of Organizational Learning Capability and Organizational Innovation on Competitive Advantage and its impact on Business Performance.

This study uses the Structural Equation Model for hypothesis testing. Schumacker and Lomax (2004), as for the normal range of receipt of the chi-square value, which is between values 1 to 3.Generally, the results of tests for the goodness fit of structural models can be seen in Table 5. The value of Chi-square $\left(x^{2}\right)$ / df-ratio is 3.90. Based on table 6, the NNFI value is 0.90 and the GFI value is 0.92 , all of these values are still acceptable because they are greater than 0.8 and close to 0.9 .For the RMSEA value is 0.03 and it is still acceptable because the value is equal to or less than 1 . So all requirements are related to goodness fit indices of structural models in the structural model have been accepted. The structural model of the RNFI must be greater than 0.9 , approaching 1 is better. RPR is use to detect structural models of parsimony degrees. Ring values start from 0.0 to 1.0 , the greater the better the goodness of fit. The RPFI is very useful for selecting models that simultaneously maximize fit and parsimony in the structural portion of the model. With a higher RPFI value, more is needed. It can be seen in Table 3, the value of RPFI is 0.41 , RNFI is 0.93 , and RPR is 0.31 , in conclusion the structural model shows the goodness of fit and parsimony. 
Table 5 - Structural Model Goodness Fit Indices

\begin{tabular}{|c|c|c|c|c|c|c|c|c|c|c|c|}
\hline Combined Mode & & & & & & & & & Struct & al Mod & \\
\hline Chi- square & DF $x 2 / d f$ & GFI & AGFI & $\mathrm{CFI}$ & $\mathrm{NFI}$ & NNFI & RMR & RMSEA & RNFI & RPR & RPFI \\
\hline 189.73 & $70 \quad 2.71$ & 0.92 & 0.94 & 0.91 & 0.93 & 0.90 & 0.04 & 0.03 & 0.93 & 0.31 & 0.41 \\
\hline
\end{tabular}

Source: Data that have been processed by AMOS.

This section will discuss the ratification of hypothesis testing. The cause and effect of the path between the variables in hypothesis testing $(\mathrm{H} 1$ to $\mathrm{H} 3)$ and the results of the study can be seen in Table 6. The results of structural model path values are shown in Figure 2. The path coefficient is Organizational Learning Capability $\rightarrow$ Competitive Advantage is 0.31; Organizational Innovation $\rightarrow$ Competitive Advantage is 0.27; Competitive Advantage $\rightarrow$ Business Performance is 0.89 . Furthermore, "Competitive Advantage» as the dependent variable, $\mathrm{r} 2$ value is 0.58 ; and "Business Performance" value of $\mathrm{r} 2$ is 0.87 . According to Kline (2016), the influence size category $r 2$ is small 0.02 , moderate 0.13 , and large 0.26 . So it can be concluded that Competitive Advantage and Business Performance have a high level of contribution. The results of path analysis can be seen in Table 6.

Table 6 - Structural Model Path Coefficient

\begin{tabular}{|c|c|c|c|c|}
\hline $\begin{array}{l}\text { Dependent } \\
\text { Variable }\end{array}$ & $\begin{array}{l}\text { Independent } \\
\text { Variable }\end{array}$ & $\begin{array}{l}\text { Standardized } \\
\text { path coefficient }\end{array}$ & t value & $\begin{array}{l}\text { Square Multiple } \\
\text { Correlation ( } \mathrm{r} 2 \text { ) }\end{array}$ \\
\hline Competitive Advantage & $\begin{array}{l}\text { Organizational Learning Capability --> } \\
\text { Organizational Innovation }\end{array}$ & $\begin{array}{l}0,31 \\
0,27\end{array}$ & $\begin{array}{l}5.70^{*} \\
8.12^{*}\end{array}$ & 0,58 \\
\hline Business Performance & Competitive Advantage & 0,89 & $23.20^{*}$ & 0,87 \\
\hline
\end{tabular}

Note: ${ }^{*} p<0.05,{ }^{* *} p<0.01,{ }^{* * *} p<0.001$. Source: Data that have been processed by AMOS.

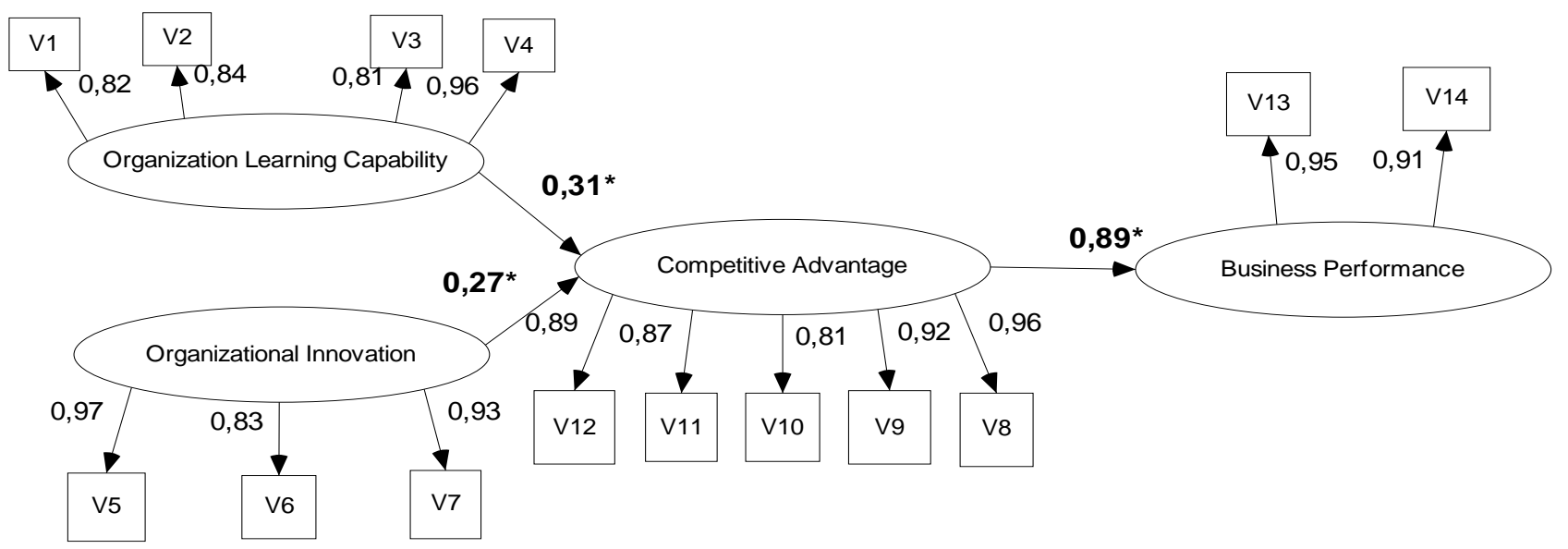

Figure 2 - Structural Model Result

\section{HYPOTHESIS ANALYSIS}

Organizational Learning Capability has positive influence on Organizational Innovation (H1 accepted). Based on Table 6 the finding analysis namely "Organizational Learning capability" have positive influence on Organizational Innovation (with the coefficient $=0.31$, $t=5.70, p<0.001$ ). It's consistent with the results of the study (Calantone et.al, 2002), (Céspedes et.al, 2005), (Moustaghfir and Schiuma, 2013), and Chen et.al (2009), that Organizational Learning Capability has significant influence and positive towards Organizational Innovation. It indicates that the implementation of Organizational Learning Capability is very important to create Organizational Innovation. MSME manager can improve Organizational Innovation by increasing the following four alternatives: (1) Managerial commitment. For example, (a) manager should have good adaptability in dealing with various changes in the business world. (b) pay attention with the employee's learning ability, because it is a key factor in the success of the company and (c) giving an 
appreciation to employees who can create innovative ideas. (2) Perspective system. For example, (a) all employees are required to know the goals to be achieved by the company. (b) all parts of the company must know and realize that they must make a major contribution in order to realize all the goals of the company. (c) all parts of the company must work together in a coordinated manner and look after each other and try to establish harmonious relationships among employees. (3) Openness and experimentation. For example, (a) the company must improve the work process with methods of increasing experimentation and innovation. (b) companies can learn from competitors about the ways they do with the aim of imitating, developing and creating value added that competitors do not have. (c) managers must pay attention to information that comes from outside as a useful tool for organizational learning. (d) managers must instill positive cultural values to employees such as openness in giving opinions and suggestions related to procedures or methods for carrying out the company's tasks to be better. (4). Knowledge transfer. For example, (a) managers should discuss, analyze errors and failures in all parts of work. (b) managers must provide opportunities for employees to open up and talk among themselves about activities, new ideas and programs that are useful for the company.

Organizational Innovation has a positive influence on Competitive Advantage (H2 accepted). Based on Table 6, the data analysis show that Organizational Innovation has positive influence on Competitive Advantage (with the coefficient $=0.27, t=8.12, p<0.001$ ). These results are consistent with previous empirical research by Camisón and Villar, (2010) and Walker et.al (2010), conclude that Organizational Innovation has positive influence on Competitive Advantage. It shows that Organizational Innovation is very important to create Competitive Advantage. an MSMEs manager can enhance Competitive Advantage by increasing the following three alternatives: (1) Organizational innovation in business practices For example (a) The company should implements a Quality Management System. (b) The company uses a lessons and knowledge and database of best practices. (c) The company implements practices for increases worker retention and employee development. (2) Innovation in workplace organizations. For example, (a) managers should implement work responsibilities more flexible. (b) manager should use decentralization in decision-making. (c) managers should implement a functional working groups. (3) The latest organizational method for external relations. For example, (a) the company should implement outsourcing business activities. (b) the company uses a method for integration with suppliers. (c) the company should collaborate with customers.

Competitive Advantage has a positive influence on Business Performance (H3 accepted). The results of the data analysis show that Competitive Advantage has positive influence on MSMEs performance (coefficient $=0.89, t=23.20, p<0.001$ ). The findings are consistent with the results of research by Kearns and Lederer (2003) and Hooley and Greenley (2005), this study supports that Competitive Advantage has positive influence on MSMEs Performance. It shows that Competitive Advantage Innovation is very important to create influencing MSMEs Performance. an MSMEs manager can increase competitive advantage by increasing the five alternatives as follows: (1) Differentiation. For example, (a) the company should increase the credibility and prestige of the organization. (b) the company should provide new products / services to customers. (c) the company should improve brand characteristics. (d) the company should provide better products / services to customers. (e) the company should accelerate the transaction. (f) the company should provide customized products / services. (g) the company should provide easier customer access to information. (2) Cost reduction. For example, (a) the company should reduce the cost of information distribution. (b) the company should reduce research and development costs (c) companies should save costs by reducing labor. (d) the company should reduce advertising costs. (e) the company should reduce communication costs. (f) the company should reduce marketing costs. (g) the company should save costs by reducing travel costs. (3) Innovation. For example, (a) the company should make efforts to use other applications to be developed more quickly. (b) the company should shorten the time period for product development (c) companies should change the way organizations do business. (d) the company should be better at coordinating business operations. (e) the company 
should ensure that previous applications are not suitable for implementation. (f) the company should respond to changes more quickly. (4) Growth. For example, (a) companies should be better at achieving organizational goals. (b) the company should increase customer satisfaction. (c) the company should improve business efficiency. (d) the company should increase ROI (Return on Investment). (e) the company should increase market share. (f) the company should increase annual sales revenue. (g) the company should increase the return on financial assets. (5) Alliance. For example, (a) companies that support close relationships with business partners. (b) companies that support it Increase efficiency in the supply chain. (c) the company seeks to access information with business partners easily. (d) companies that are willing to take over or send information or request by a business partner. (e) the company's success helps to build beneficial relationships with other organizations.

\section{CONCLUSION}

In Conclusions Organizational Learning Capability and Organizational innovation have a positive influence on the Competitive Advantage and Business Performance. The Role of Organizational Learning Capability, Organizational Innovation, Competitive Advantage on Business Performance is based on existing research findings with changes in the business environment, these roles can change over time. Based on previous research, this research has limitations and suggestions for future researcher. Limitation of this research only focused on MSMEs in Pragaan District, Sumenep Regency, so that the results of this research cannot be generalized to other companies. This research focused on the MSMEs sector in the Pragaan District. Future studies can expand the results by analyzing other cities including large companies. The purpose of this research is to analyze in detail the Role of Organizational Learning Capability, Organizational Innovation, and Competitive Advantage in a certain period of time and its influence on the Business Performance. However, the effect of some variables may change over time so that the results also change. Therefore, this research suggests that future studies can develop research models to obtain more comprehensive results / information.

\section{REFERENCES}

1. Anderson, J.C. \& Gerbing D.W. (1988). Structural equation modeling in practice: a review and recommended two step approach. Psychological Bullentin, 103,411-423.

2. Bansemir. (2013). Organizational Innovation Communities. Springer Gabler. Germany.

3. Bentler, P.M and Chou, C.P. (1987). Practical issues in structural modeling. Sociological Methods and Research, 16, 78-117.

4. Calantone, R. J., Cavusgil, S. T., \& Zhao, Y. (2002). Learning orientation, firm innovation capability, and firm performance. Industrial Marketing Management, 31, 515-524.

5. Camisón, C., \& Villar-López, A. (2010). An examination of the relationship between manufacturing flexibility and firm performance: The mediating role of innovation. International Journal of Operations and Production Management, 30, 853-878.

6. Céspedes Lorente, J.J. et al (2005). Las prácticas de recursos humanos de alto rendimiento y la capacidad de aprendizaje organizativo. Incidencia e implicaciones. Cuadernos de Economía y Dirección de la Empresa, 24, 29-56.

7. Chaubey, A. et al (2019). Relationship of transformational leadership with employee creativity and organizational innovation. Journal of Strategy and Management.

8. Chen, H.H. et al (2009). Drivers of dynamic learning and dynamic competitive capabilities in international strategic alliances. Journal of Business Research, 62, 1289.

9. Chen, Q., Wang, C. H., \& Huang, S. Z. (2020). Effects of organizational innovation and technological innovation capabilities on firm performance: evidence from firms in China's Pearl River Delta. Asia Pacific Business Review, 26(1), 72-96.

10. Cross, Robert $L$ dan Sam Israelit.(2009). Strategic Learning in a Knowledge Economy: Individual, collective, and Organizational Learning Process.Butterworth-Heinemann .USA 
11. Fornell, C. (1981). Evaluating structural equation models with unobservable variables and measurement error. Journal of Marketing Research, 18, 39-50.

12. Hooi, L. W. (2019). Firm performance: is organizational learning capability the magic wand?. International Journal of Productivity and Performance Management.

13. Hooley, GJ \& Greenley, GE. (2005). The resource underpinnings of competitive positions'. Journal of Strategic Marketing, vol. 13, no. 2, pp. 93-116.

14. Hooper, D., Coughlan J., \& Mullen M.R. (2008). Structural Equation Modelling: Guidelines for Determining Model Fit. The Electronic Journal of Business Research Methods, 6(1), 5360.

15. Howard B. Kaplan dan Marshall Scott Poole.(2012).Organizational Innovation: Studies of Program Change in Community Agencies.Kluwer Academic/ Plenum Publishers. NY.

16. Jafari, S. (2019). The Role of Enterprise Resource Planning System Usage on User Satisfaction and organizational learning capabilities. Int. J. of Schooling, 1(3), 1-14.

17. Kaplan, D. (2000). Structural Equation Modeling Foundation and Extensions. London.

18. Kearns et al (2003). A Resource-Based View of Strategic IT Alignment: How Knowledge Sharing Creates Competitive advantage. Decision Sciences, 34(1), 1-29.

19. King, William R.(2009). Knowledge Management and Organizational Learning.Springer Cham Heidelberg. New York.

20. Kline, Rex B. .(2016).Principles and Practice of Structural Equation Modeling, Fourth Edition. The Guilforf Press. New Rork: London.

21. MacCallum, R.C. et al (1996). Power Analysis and Determination of Sample Size for covariance Structure Modeling. Psychological methods,1(2), 130-149.

22. McGrath, Rita Gunther.(2013). The End of Competitive Advantage: How to Keep Your Strategy Moving as Fast your Business. Harvard Business Riview press. USA.

23. Migdadi, M. M. (2019). Organizational learning capability, innovation and organizational performance. European Journal of Innovation Management.

24. Moustaghfir, Schiuma (2013). Knowledge, learning, and innovation: research and perspectives. Journal of Knowledge Management; Kempston Vol. 17, Iss. 4,

25. Nandram, Sharda S. (2014). Organizational Innovation by Integrating Simplification: Learning from Buurtzorg Nederland. Springer Cham Heidelberg. New York.

26. Phan, T. T. A. (2019). Does organizational innovation always lead to better performance? A study of firms in Vietnam. Journal of Economics and Development.

27. Salisu, Y., \& Mohammed, S. (2019). Learning Capability and the Performance of Small and Medium Enterprises in Developing Economies: The Role of Absorptive Capacity. Journal of Economic Info, 6(1), 49-55.

28. Schumacker, R. E., \& Lomax, R. G. (2004). A beginner's guide to structural equation modeling, Second edition. Mahwah, NJ: Lawrence Erlbaum Associates.

29. Shams, S. M. Riad. (2013). E-Marketing in Developed and Developing Countries: Emerging Practices. Australia:Central Queensland University

30. Spott, Harlan E. (2015). Creating and Delivering Value in Marketing: Proceedings of the 2003 Academy of Marketing Science (AMS) Annual Conference. Springer Cham Heidelberg. New York.

31. Waheed, A. et al (2019). How new HRM practices, organizational innovation, and innovative climate affect the innovation performance in the IT industry: A moderatedmediation analysis. Sustainability, 11(3), 621.

32. Walker G. (2009). Modern competitive strategy (3rd ed.). New York: McGraw-Hill.

33. Walker, R. M., Damanpour, F., \& Devece, C. A. (2010). Management innovation and organizational performance: The mediating effect of performance management. Journal of Public Administration Research and Theory, 21, 367-387.

34. Yusoff, Y. M., Omar, M. K., \& Mohd, I. H. (2019). The perception on organizational learning capability. Evidence from Malaysian manufacturing SMES. International Journal, 2(8), 53-59.

35. Zhou, Y., Fan, X., \& Son, J. (2019). How and when matter: Exploring the interaction effects of high-performance work systems, employee participation, and human capital on organizational innovation. Human Resource Management, 58(3), 253-268. 